ENTREVISTA 


\section{NO CALOR DA OBRA: ENCONTROS COM A PRODUÇÃO CULTURAL CONTEMPORÂNEA Entrevista com o escritor Cristovão Tezza}

Em uma noite de sexta-feira, 7 de agosto de 1998, logo depois de ter falado durante mais de duas horas para um auditório lotado, o escritor Cristovão Tezza concedeu esta entrevista a seus colegas, professores de literatura do Departamento de Linguística, Letras Clássicas e Vernáculas da UFPR. Professor de língua portuguesa na mesma universidade, Cristovão falou sobre algo que 0 fascina: a narrativa, especialmente a narrativa literária. Como acontece na estrutura narrativa clássica - uma coisa levando a outra - a conversa se estendeu um bocado. O ficcionista foi e voltou em seu percurso literário, desde as comparações entre Trapo (1988) e Uma noite em Curitiba (1996), até a repercussão de seu romance mais recente, Breve espaço entre cor e sombra (1998), passando pelas diferentes versões de Juliano Pavollini (1989) e pelos dois títulos de Aventuras provisórias (1989). No epílogo (provisório) desse percurso, aparece a reescrita de Ensaio da paixão (1986), cuja segunda edição deverá ser lançada no início de 1999.

Escrito em 1981, Ensaio da paixão é inspirado em experiências dos anos 70 , época em que o autor vivia em uma comunidade alternativa, liderada por W. Rio Apa. O teatro e a literatura faziam parte de seu cotidiano. Algumas de suas aventuras (provisórias?) daquela época foram lembradas na entrevista, tendo como contraponto a aventura renovada a cada dia: ser um escritor reconhecido nacionalmente que vive e produz na mesma cidade de Dalton Trevisan, Paulo Leminski e Poty Lazarotto.

Depois de tantas histórias, opiniões e risadas, já tarde daquela noite em Curitiba, Cristovão Tezza ameaçou: "Às vezes você pensa: vou ser igual ao Dalton, não vou falar com mais ninguém..." Na seqüência, veio a confissão: 
"Eu vou me sentir ridículo! Eu não sou assim! Eu sou um cara que adora conversar, bater papo com as pessoas..." Ele não estava mentindo.

Benito Rodriguez - Entre Trapo e Uma noite em Curitiba há uma relação quase que especular em termos de trajetória de gerações. Enquanto lá no Trapo você tem o professor, já aposentado, experimentando uma vivência vicária através do processo de reordenação dos textos do jovem, no Uma noite em Curitiba você tem o filho que vive essa experiência vicária através dos textos do pai. Isso só já daria um mote de comparação, mas também gostaria que você respondesse, como uma segunda pergunta, já embutida nisso: no final do Trapo, a despeito da questão da experiência vicária, das precariedades e do próprio suicídio do Trapo, há uma certa possibilidade de reconciliação do professor consigo próprio e até a perspectiva da construção de uma relação digamos, um final, senão propriamente feliz, que aponta para uma perspectiva...

\section{Cristovão Tezza - Otimista.}

Benito - Otimista, eu não queria usar a palavra... se você usou fica mais fácil. No caso de Uma noite em Curitiba, digamos que a perspectiva é algo sombria.

Cristovão - É verdade, eu não tinha pensado nessa relação especular, como você falou. Essa semelhança, até as cartas... Realmente, não foi consciente. O centro de Uma noite em Curitiba, para mim, era a trajetória do professor, típica de uma geração meio silenciada ao longo dos anos 70 e 80 . E, ao mesmo tempo, peguei a experiência do que eu achei mais contrário do acadêmico possível, que era o teatro. Era uma experiência direta que eu tive na adaptação do romance Trapo para o teatro, que foi feita com atores de alto nível, Marcos Winter, Imara Reis, Cláudio Mamberti, e eu de certa forma convivi com um tipo de estrelato que usei tematicamente no livro, em oposição, para iluminar o professor Rennon. $O$ resto seguiu uma estrutura mais ou menos intuitiva.

Quanto ao otimismo que desaparece, é verdade. O Trapo é um livro romântico, ele tem um forte traço romântico, uma relação esperançosa com o mundo e com a vida. $O$ professor Manuel se transforma numa pessoa melhor do que ele era. Sobre a memória de Trapo, ele se torna 
uma pessoa melhor. É uma visão de mundo mais luminosa, provavelmente refletindo o que eu era quando escrevi. Nos anos 80 , eu acho que era um sujeito bem mais alegre... Provavelmente isso se refletiu no livro. Uma noite em Curitiba, não: é um livro cínico, frio, escrito sob uma visão de mundo bem mais sombria, bem mais fechada. A relação familiar, ali, tem uma frieza que, por exemplo, a relação familiar do Trapo não tem: era mais explosiva. Em Uma noite em Curitiba, as relações familiares são encalacradas: o filho não sai de casa, vive aquela relação ambígua com a mãe, com o pai. É um livro mais pesado. Mas não foi consciente não.

Quanto à presença das cartas, como gênero literário, a epístola, eu acho um negócio fantástico, porque é uma voz que você pode colocar de uma forma absolutamente intcira, e ao mesmo tempo há todo um jogo de pressupostos e entrelinhas. Essa é a impressão que dá ao você escrever para revelar uma pessoa pela carta. Quer dizer, a carta tem toda uma formalidade, de esconder mais do que revelar. E me interessa também como registro de linguagem, todas as nuances possíveis. Aliás, o gênero carta vai reaparecer de novo no Breve espaço, também, mas agora como um tipo de confessionário.

Acho engraçado que alguns críticos - agora os críticos estão dizendo como os escritores devem escrever... talvez seja o momento de o escritor dizer como os críticos devem criticar [risos]... - digam que não se deve mais escrever em primeira pessoa. Como se houvesse alguma outra pessoa que escreve. Quer dizer, o aspecto formal, se é $e l e$, ou $e u$, isso é absolutamente irrelevante, na construção do ponto de vista... ela é primeiríssima pessoa sempre, não é?

Patrícia Cardoso - Aí fica romântico demais...

Cristovão - [risos] É, é romântico demais... É claro, é um aspecto só formal. Mas, então é isso, algumas obsessões minhas voltaram, fortemente biográficas. Eu tinha uma insegurança, que acho que estou começando a perder, de só escrever sobre o que eu me sentisse extremamente firme, só escrever sobre aquilo cujo universo de referências eu conhecesse, digamos, à flor da pele. O professor Rennon, eu conheço. São dez anos de rampa aqui na Universidade [risos]. Quer dizer, tem um universo de referência aí que você conhece: você vai, bebe o cafezinho... O tipo de referência do professor Manuel, do Trapo, já era 
uma outra experiência. Na época do professor Manuel eu não saberia escrever sobre um professor universitário com tanta verossimilhança. Ele é um professor de $2 .^{\circ}$ grau. É um pouco bobagem minha, como um lastro para me sentir seguro. Mas você não precisa muito desse suposto "realismo". Depois de um certo momento, isso já deixa de ser relevante. É uma questão de segurança técnica.

Raquel Bueno - Além dessas semelhanças que o Benito levantou, uma coisa que me chama a atenção são as mediações: uma personagem fala de outra, ou recebe carta, ou é indiscreta e acaba descobrindo cartas do pai que foram escritas para outra pessoa. Sempre tem um narrador, mas o drama mais pungente que cada romance traz nunca é o dele próprio. Em Aventuras provisórias também é assim: o drama maior é do Pablo. No Breve espaço, o Tato e a italiana dividem a coisa, mas, acredito, o drama pessoal mais intenso é o dela, que escreve a carta, e não o do narrador. É sempre uma mediação em que aquele que promete ser o protagonista acaba não sendo. Isso é deliberado, tem a ver com a questão do pluridiscurso? Ou é por acaso: o drama do outro cresce mais? Ou será que essa coisa meio voyeur, meio indiscreta, faz com que a experiência vampirizada, a experiência do outro seja mais intensa do que a tua própria, para te inspirar?

Cristovão - Bom, tudo isso são técnicas da mentira [risos], quando você trabalha com esses pontos de vista que vão se iluminando. Agora, é um processo intuitivo. Por exemplo, a italiana só apareceu no Breve espaço lá pelo terceiro ou quarto capítulo da história do Tato, quando eu senti necessidade de ter uma referência fora. Foi o maior risco que eu corri como escritor, porque eu estou trabalhando com uma personagem estrangeira, e sobre uma área que não é exatamente a minha, quer dizer, de artes plásticas, e tudo. Era uma situação complicada... e além disso uma mulher... quer dizer, eu podia ter caído do cavalo. Até hoje eu não sei, ainda, se caí do cavalo [risos]. Mas as pessoas gostam, eu sinto que a história da italiana pega muito. É uma coisa intuitiva: eu preciso iluminar uma linguagem com outra; quando eu tenho uma fala só, me dá uma sensação de falta de densidade, falta de perspectiva, da idéia mesmo de terceira dimensão. É uma outra voz que dá uma referência. O Tato ilumina a italiana, e vice-versa, mesmo não tendo eles nenhuma relação narrativa imediata. Está um em cada mundo, sob uma relação 
distante, tênue. A mesma coisa que eu senti a primeira vez, bem objetivamente, no Juliano Pavollini. A primeira versão do livro não tinha a psicóloga, a Clara. Na segunda versão ela entrou, sutilmente, mas presente em vários pontos do livro, já desde a primeira frase. Ele está escrevendo aquele livro para uma psicóloga, na cadeia, e isso muda tudo, isso dá uma terceira dimensão para o texto, relativiza uma vez a mais. Ele está escrevendo para ele - ele mesmo diz - c para outra pessoa. Ele tem que simular uma imagem dessa pessoa, e escondidinho está o leitor, que está lendo os dois, para quem afinal o texto se dirige. E o narrador, que está organizando isso. Eu penso que uma linguagem não se ilumina sem a outra. Agora, muito curiosamente - lembrei ao escrever recentemente um texto sobre o Rio Apa para a Revista Letras - o primeiro livro que o Rio Apa escreveu, Um menino contemplava o rio, contém duas narrativas que vão se intercalando [risos] e se passa uma no navio e outra no litoral da Venezuela. É um livro que tem uma construção sofisticada, se bem que eu acho que literariamente é mal resolvido. $O$ Rio Apa sofreu sempre o problema da doutrinação, ele escrevia livrostese, e aí a coisa fica pesada, fica datada. Mas aquela estrutura me intrigou, eu acho, e eu nunca tinha pensado objetivamente nisso antes. Eu li esse livro lá por 68,69 . É possível que isso tenha ficado na minha cabeça, tenha sido uma referência, a de narrativas cruzadas.

\section{Luís Bueno - Não o Vargas Llosa?}

Cristovão - Não, curiosamente não. Outro livro que me marcou bem, nessa idade - 15, 16 anos - que eu achei a construção de uma catedral magnífica de literatura, é o Contraponto, do Aldous Huxley. Quando li, eu disse: "Isso aqui é literatura perfeita!" [risos] É muito engraçado: é claro, você vai reler e vai ver que tem um monte de coisas datadas. Mas é aquela construção de várias línguas simultâneas. E ele tinha um hiperrealismo. O realismo dele dava uma ilusão brutal de realidade. Contraponto foi traduzido pelo Érico Veríssimo, edição da Globo. Essa foi uma leitura que marcou. Então, a gente não sabe de onde vêm essas coisas para dar força. O que fica bem claro é que ninguém escreve sozinho. A literatura se faz de literatura, mesmo. Quanto mais você vai ficando velho, vai olhando para trás e vai vendo que sofre fios de influência, coisas que vão tomando conta. $O$ grande desafio é você ter uma linguagem própria 
no meio desse emaranhado de linguagens já prontas à disposição. Todo escritor se pergunta: onde é que está a minha voz?

Luis - Deixa eu aproveitar um pouquinho o que você acabou de dizer sobre um discurso rebater o outro. $\mathrm{O}$ Temístocles Linhares diz que o Graciliano Ramos não dava bola para o leitor: ele escreve um livro fininho, mas duro, difícil, que não tem nada que dê curiosidade de saber o que vai acontecer em seguida. Seu texto é o contrário disso. A gente poderia dizer que, além da diversidade das vozes internas tem esse rebatimento com o leitor também?

Cristovão - Tem, num segundo plano, da origem. Eu tenho o fascínio da narrativa. Fui um leitor, por exemplo, de policial. Li Agatha Christie, Simenon... Júlio Verne, eu era fascinado, quando guri... 14, 15 anos. A narrativa me fascinava. E uma das imagens que eu tinha de literatura, era "como deve ser difícil escrever uma história... assim" [risos]. $\mathrm{O}$ leitor quer saber como deve ser difícil criar o suspense. Isso é uma imagem infantil, bem infantil, não é nem adolescente. Depois eu fui tomando um outro rumo. Você pega os contos de $A$ cidade inventada $\mathrm{e}$ não tem nada disso. Aí é, entre aspas, alta literatura, sofisticada, borgiana, cheia de imagens transcendentes. Já no seguinte, o Gran Circo das Américas, não. Ali eu estava preocupado, eu queria dominar uma estrutura narrativa convencional. $\hat{E}$ uma coisa que me atrai, eu acho legal, eu gosto, eu acho que a estrutura narrativa da história clássica, do "uma coisa levando a outra", ela é uma das essências, um dos elementos fundamentais da prosa. Ela está presente, mesmo no texto mais hermético. Digamos: isso tem até no Beckett, aqueles "textos para nada". Parece que você lê cinco páginas e não vê nada, é uma coisa impressionante. Ele consegue escrever sobre coisas que não são corpóreas. Mas mesmo ali você tem um fio narrativo. Tem uma história que é um sujeito subindo uma escada e depois voltando, e subindo uma escada e depois voltando, e você não vê nada, você não sabe quem é o sujeito, não é nada... Ele conta os degraus das escadas milhentas vezes. Mas é claro que não se perde o fio narrativo. É a questão da própria aquisição da linguagem. Eu vou tão longe ao ponto de considerar que a narrativa é um dos elementos constitutivos da linguagem. $E$ me atrai, me dá um fascínio saber que com pouquíssimos elementos você é capaz de amarrar um leitor... Por exemplo, a história da italiana: não ocorre 
praticamente nada. Num momento, acontece uma viagem de trem. Aquela cena do trem, você vai criando sobre coisa nenhuma. É um encontro que você já sabe que não deu certo, o leitor já sabe, mas você fica remoendo aquilo, trabalhando. Não sei explicar. Num primeiro momento, é isso aí: o amor à narrativa, mesmo, me atrai.

Num segundo momento, é técnico. Aí você tem que saber dominar. Por exemplo, a estrutura narrativa não pode ser simplesmente uma seqüência gratuita de cenas. No Ensaio da paixão, um livro de formação, ainda tem muito disso. O Ensaio da paixão é mais ou menos uma sequiência aleatória. Os primeiros capítulos vão entrando meio ao acaso, entra um personagem, aparece outro, não tem um fio que amarre a primeira cena à outra. Você pode até inverter os capítulos. Só depois da invasão do exército a coisa fica mais ou menos amarrada a uma sequiência obrigatória. O Ensaio não tem uma estrutura novelesca, no sentido, digamos, do folhetim. Ao rever o livro, que será agora reeditado, eu tive também um certo cuidado com isso. Na primeira parte, não dá mesmo para mexer. Eu amarrei mais a segunda parte para dar uma estrutura mais fechada. Aí, sim, tem que tomar cuidado: a unidade do conjunto. A primeira página tem que ter a ver com a última. Se você tirar um tijolo dali, ele desmonta... Todas as cenas são relevantes. Eu tento dar uma boa fechada na organização estrutural. Não é simplesmente o suspense pelo suspense, não, que é a coisa do folhetim.

Patrícia - Como você vê a leitura que a crítica fez do seu último romance, de que você enveredaria nele pelo romance policial? Qual é a sua leitura da leitura da crítica?

Cristovão - Bem, a crítica brasileira vive satanizações inexplicáveis. De repente, por exemplo, descobriu-se que Rubem Fonseca é a pior desgraça que aconteceu na literatura brasileira. É uma coisa recorrente. Ele foi o maior nome e agora cada livro dele tem que ser malhado - está na moda falar mal do Rubem Fonseca. Junto com isso, aparecem dogmas curiosos: não pode ter um cadáver. Um livro que tem um cadáver está condenado a ser uma desgraça, não é? Ele é um reles romance policial [risos]. E o mesmo espaço cultural que dá páginas inteiras para o Hammet e para o Chandler diz que a Patrícia Melo é ruim porque escreve livro policial. Então, parece que a crítica está há muitos anos com uma moldura pronta na mão, atrás de um romance brasileiro que se encaixe 
naquilo. Esse é o primeiro aspecto. Talvez seja o momento de a crítica aguçar o ouvido e simplesmente ouvir, mais generosamente, qual a produção real da literatura, o que o Brasil está de fato escrevendo - isso me parece um bom ponto de partida crítico. No segundo aspecto, agora pessoal: o traço policial talvez seja uma herança desse meu gosto de ler policial, pela estrutura de suspense, pela estrutura narrativa. Mas se você pegar, por exemplo, o cadáver de Uma noite em Curitiba, ele é extremamente funcional. Quem morreu foi um cara, numa manifestação estudantil de 68, que tem tudo a ver com o trajeto do Frederico Rennon. Não é uma história policial, de modo algum, é apenas um gancho, organicamente ligado com a visão de mundo dele. Ele não matou um cara numa situação, digamos, policial, e está se escondendo. Não, era uma coisa da época de estudante, etc., que estava ligada com o bem e o mal, com a questão da luta armada. Tinha toda uma relação ideológica com aquele período histórico. Já nesse caso [Breve espaço entre cor e sombra], é só a cabeça do Modigliani, não tem cadáver. $\mathrm{O}$ que eu acho é que esses elementos, por si sós, não são de fato relevantes como parâmetro crítico. Não há nada de mal que um livro tenha uma estrutura policial. Resta saber qual é a extensão, qual é a estatura do texto, o que ele consegue com isso, se ele é só isso, se ele é um pouco mais do que isso, se é muito mais que isso. Eu gostei, por exemplo, do que o José Geraldo Couto escreveu (uma coisa que eu não tinha pensado objetivamente antes), que o suspense é um argumento para eu fazer a minha literatura. Ele diz: "Em Hitchcock, acontece o contrário; a narrativa era um argumento para ele criar suspense". O importante é criar o suspense, o resto... Para mim, não; o suspense não tem importância, ele é apenas o argumento para outra coisa. Eu acho que é mais ou menos isso. Tanto que ele acaba se esvaziando, é mais um pano de fundo que vai revelar um pouco dos personagens, da relação entre eles.

Marcelo Sandmann - Alguns personagens de livros seus são pessoas que estão às voltas com a criação, às voltas com a produção em algum campo. Ou na literatura, ou, no caso desse teu último romance, nas artes plásticas. Acontece uma coisa que eu acho bastante curiosa e recorrente. De alguma forma esses personagens (no caso da literatura, eu penso no romance $A$ suavidade do vento) querem criar tendo como referência grandes nomes da literatura (como Clarice Lispector) ou então 
têm uma referência cultural, como o I Ching, que é consultado constantemente. Mas, no instante em que vão produzir efetivamente a sua obra, ou viver a sua vida cotidiana, se vêem completamente cindidos desse alto referencial ao qual eles aspiram. $O$ que a gente percebe no caso do Juliano Pavollini é uma falência e uma desistência da atividade de escritor. No caso do Trapo é uma desistência da própria vida, e como a vida e a obra ali são uma coisa só, automaticamente a obra é expelida, também. Por que isso aparece com tanta frequiência, Cristovão? Você já tentou pensar? Por que esses criadores não se realizam ou se realizam de uma forma indireta, como o próprio professor Manuel, que se torna um homem melhor, como você mesmo disse, ou o Juliano Pavollini, que narra como uma forma de terapia, também? Esses personagens que se afirmam através da literatura, através da criação, no seu romance, o fazem não em função de um projeto estético. $O$ projeto estético acalentado, projetado para cima, não se efetiva. Dá para se pensar um pouco a cisão entre esses dois tipos de criadores, que eu reconheço?

Cristovão - Eu sou... tudo indica que eu sou um escritor pessimista, não é? [risos] Talvez o livro mais otimista, curiosamente, seja o Trapo. Por exemplo, vou falar do Breve espaço: não é um livro sobre pintura, é sobre um pintor. Assim como o Matozo; o livro A suavidade do vento não é um livro sobre literatura, mas sobre aquele produtor de literatura, aquele escritor. Muito sintomaticamente, o título original do livro Aventuras provisórias era $O$ elogio do fracasso. Eu acho que o fracasso como tema literário é uma coisa muito rica. Ele me dá uma dimensão que eu posso trabalhar. Depois, a questão do inadaptado. Todo personagem meu é inadaptado, ele não tem lugar no mundo. Eu estava falando hoje sobre a minha geração. É uma geração de inadaptados. A morte do Trapo é mais ou menos uma morte sociológica, porque foi um período de poetas suicidas. $O$ próprio Paulo Leminski tem uma certa trajetória de suicídio. Ele morreu de cirrose, com trinta e poucos anos. Era uma época meio louca, do cara se entregar, identificar a arte com a vida, não separar, não ter essa relação segura de distância. Isso entrou no livro... Você estava perguntando por que são projetos que se frustram?

Marcelo - Esses personagens que se colocam a tarefa de realizar uma obra se frustram, e aqueles que a realizam, o fazem a despeito de projetos 
estéticos. Funciona como uma espécie de cano de escape, ou de terapia, ou de encontro consigo mesmo através da criação.

Benito - Ou de fonte de renda...

Cristovão - É, no caso do narrador do Uma noite em Curitiba, é verdade.

Adalberto Müller - Parece que o Benjamin, ele tinha chamado a atenção para essa diferença. Parece que, em geral, essa é uma característica do romance, como forma narrativa. Quer dizer, o Benjamin compara a epopéia ao romance, e do romance como a aventura do incomensurável, da luta do homem com o incomensurável.

Cristovão - É uma história de um fracasso.

Adalberto - É, o fracasso está sempre presente, quer dizer, a impossibilidade de o indivíduo vencer as estruturas, os sistemas.

Patrícia - Você falou lá embaixo, que a sua entrada para a literatura foi através da ética e não da estética. Em sua mudança mais em direção ao ponto de vista estético eu sinto que permaneceu um elemento ainda ligado ao ético: é que, principalmente nos dois últimos romances, você trabalha com personagens que beiram ou um paradigma, ou quase um estereótipo. E você não tem - principalmente em Uma noite em Curitiba - aquela volta que você diz que acontece no Trapo, de uma redenção ou um reencontro do personagem. Ou seja, você opta por uma visão de mundo ou por um comportamento social que não leva a nada, pois é uma escolha que leva ao fracasso. Pelo menos é minha impressão. Gostaria que você fizesse um comentário a esse respeito.

Cristovão - Eu acho que isso que vocês estão falando está interligado à visão de mundo da minha literatura, que é uma coisa sobre a qual eu não tenho controle. Eu acho que aquilo que você disse, essa minha origem, de $o$ ato de escrever como um ato existencial e não um ato estético - claro que hoje é um pouco diferente - cla permanece. $O$ romance, para mim, é um espaço de investigação temática, também. 
Uma coisa que me magoava - ou que eu achava assim, no tempo em que eu ficava magoado [risos] - era quando diziam que eu não tinha apuro formal. Eu me lembro, na época do Trapo diziam assim. O próprio Leminski fala isso no posfácio. Como se a linguagem romanesca fosse uma linguagem poética. E ela não é, ela tem um outro tipo de estrutura. $\mathrm{Ou}$ quando dizem que a estrutura dos meus livros é inacabada. Por exemplo, - Breve espaço entre cor e sombra, ele é uma estrutura que pára na metade; ele parece que não tem estrutura, não é? Mas isso é exatamente o que é, uma coisa meio cubista, mesmo. É um tipo de evolução minha. $O$ Trapo é um livro fechadinho, ele é organicamente fechado. Depois escrevi livros que não são bem assim, que vão ser mais inacabados. Eu estou vendo, por exemplo, que no Ensaio da paixão curiosamente essa desorganização estrutural pode ser até uma vantagem, hoje. Eu estava pensando que isso era um signo de modernidade [risos]. É claro que eu sempre penso essas coisas em meu favor [risos]. Mas é curioso, ele não obedece a uma exigência estrutural que seria típica de um romance convencional. Sobre isso eu me lembro que entre 67 e 68, fui ver uma palestra no primeiro grande concurso de contos que teve aqui. Foi na Associação Atlética Banco do Brasil. Veio o José Condé, veio o Adonias Filho, grandes nomes da época, Marques Rebelo. Então eu fui lá, cheio de livros, pra pegar autógrafo, todo entusiasmado. Eu tinha lido o Massaud Moisés, $A$ criação literária, e alguém falou sobre novela. Então eu fiz uma pergunta para um deles, muito feliz com o meu achado, sobre a distinção entre novela e romance do Massaud Moisés, para falar do Érico Veríssimo. E ele: “O tempo e o vento é uma rapsódia." Aí eu disse: "Pronto, bagunçou o meu esquema formal. Eu estava entendendo tão bem a coisa..." [risos]. Mas - voltando - eu vi o Marques Rebelo dizer que Dostoievski era um péssimo escritor. Por que era um péssimo escritor? Porque não sabia acabar os livros dele. [risos] "Os livros dele são tecnicamente frouxos, não têm estrutura formal." Pô, mas essa era uma grande qualidade! Quer dizer, eles querem reduzir o romance a uma estrutura formal fechada. Claro que não é também só o contrário, ele tem que ter... ele tem uma rigidez interna. Às vezes você pode ter outra contraposição. Tem um fundo no que escrevo que é temático, mesmo. Eu não sei reconhecer bem o que é. A desgraça é que as coisas se encaminham pessimistas, não é? Agora, esse é o espaço da literatura, mesmo, porque toda a indústria do entretenimento, o cinema, mesmo a literatura de consumo, etc., trabalham sob o pressuposto da esperança e da felicidade. O cinema americano, que todo mundo consome, todo ele tem que ter um 
final feliz. Se você pensar o efeito que isso faz no imaginário de milhões de pessoas diariamente, que estão consumindo a novela de televisão, etc. Você pode ter todos os problemas do mundo, desde que você restaure a esperança e o bem. No fundo não muda. Então, a literatura é um espaço ao contrário. Eu não quero repetir a visão de mundo do entretimento. Não me interessa trabalhar com isso.

Adalberto - É um espaço de negatividade.

Cristovão-É, para mim ela acaba sendo. Eu estou querendo problematizar. As pessoas são muito complicadas, o mundo é complicado, eu sou complicado. É sobre isso que eu trabalho. É essa a minha matéria. Sem falsificar. Quer dizer, sem chegar no final e dar um nozinho. No fundo, a grande massa de entretenimento trabalha com isso: o grande produto que ela vende é a esperança.

Adalberto - Retomando o que eu estava falando do Benjamin, parece que isso é uma característica não da literatura, mas sobretudo da obra romanesca. É claro que isso acontece todo dia, mas a partir do momento em que você insere o indivíduo dentro do mundo, o personagem dentro do mundo, e tem uma pretensão séria de fazer isso, quer dizer, o final é previsto, de certa maneira. A coisa vai pro negativo, mesmo. Quer dizer, muito dificilmente na prosa de ficção a gente tem casos como o de Guimarães Rosa. São raríssimas exceções que tendem a uma transcendência. Em geral, a forma romanesca está fadada a esse destino trágico.

Cristovão - Tem uma história que está me interessando agora. Na área acadêmica, mesmo... não estou nem vendo a minha obra entrar nisso de alguma forma. O Brasil passa por uma transformação nos últimos cinquienta anos, violentíssima, de um mundo rural para um mundo urbano, e isso certamente tem conseqüências na visão de mundo que vai transparecer na literatura. E não é simplesmente uma mudança geográfica, ou de espaço físico. É uma mudança de relações mentais. Por exemplo: Guimarães Rosa é o mítico que se fecha como mito. No fundo, ele dá uma explicação, uma resposta mágica. Aí você pega a cidade, o anti-Guimarães Rosa que é o próprio Rubem Fonseca (para dar um exemplo contemporâneo), desde a linguagem. A linguagem mais 
rasteira e coloquial, entre aspas, mais "chã", menos poética possível, para uma visão de mundo de relações abstratas, sem mito nenhum. Eu estou em algum lugar dentro dessa mudança. Apesar de poder ser classificado como uma literatura regionalista, que se passa em Curitiba, etc., eu vivo um espaço mental, eu acho, profundamente urbano, não mítico, não mágico, e que só é solidário ou comunitário por acaso, não por essência. São solidões que estão tentando achar um lugar, como se diz, uma fresta de salvação. Eu acho que isso está presente em tudo que eu escrevi. Curiosamente, o Ensaio da paixão tem alguma coisa de mundo mágico e mítico que era ainda herança da comunidade rioapeana e dos meus anos de formação. E eu acho que é só o Ensaio, porque os outros livros meus trabalham com um mundo que é negativo mesmo, que vão negar os processos de comunhão humana. Talvez - mas isso é sonho como a expressão de um desejo de restaurá-la sobre um outro patamar.

Raquel - Você consegue imaginar escrever o Ensaio da paixão hoje? Você reescreveu, e o guia foi o texto. Digamos que a proposta tivesse sido escrever uma narrativa sobre aquela época, em que se acreditava bem ou mal - na anarquia, na comunidade alternativa. $O$ texto que você teria escrito teria sido muito diferente, se não houvesse o texto-base?

Cristovão - Certamente, teria sido. Eu não teria capacidade. Eu até me surpreendi e tive de me controlar para não carregar de ceticismo ou de amargura, principalmente a primeira parte. Se bem que não é um livro tão... paradisíaco, digamos assim. Ele tem um sabor agradảvel de anarquia, mas é uma anarquia muito violenta, as pessoas são muito agressivas. Os personagens do Ensaio da paixão vivem a porradas. Eles têm uma franqueza, uma transparência quase que absurda, e que chega a ser quase inocente. Parece que é como se no paraíso você falasse assim, as pessoas dizem na cara...

Raquel - Algo primitivo...

Cristovão - Exatamente, tem uma agressão, e passa a fazer parte daquele jogo. Mas, mesmo assim, hoje eu teria um outro olhar. Eu criei figuras míticas. O Isaías é uma figura mítica. Eu respeitei o Rio Apa profundamente... e tirei do romance, também. Ele fica só na montanha 
[risos]. Foi uma maneira de respeitar o mestre. Acho que o Rio Apa fica até hoje com um pé atrás com esse livro, porque não teve chance de doutrinar [risos]. É um pressuposto ali... E era muito engraçado, porque nos ensaios da Paixão, no tempo da comunidade, você tinha claramente uma hierarquia, entre aspas... Tanto que eu fui acusado uma vez, pelo Bill - um dos atores, que, por sinal, depois foi para os Estados Unidos - ele dizia que eu era um dos... como é que ele dizia? Que eu era "da turma do Rio Apa". Quer dizer, morava tudo junto, mas eu era "da turma do Rio Apa" [risos], o que significava indiretamente, que eu era "do lado do poder" [risos]. Então, tinha os marginais, o pessoal que puxava fumo, e tinha o pessoal mais careta. Até que um dia o Rio Apa teve que dar uma mijada, às nove horas da manhã: "Ou vocês param de puxar fumo, ou esse teatro não vai pra frente!' Porque tinha dias em que chegava tudo cambaleando de manhã para ensaiar. Não conseguiam trabalhar. Isso em alguns períodos, episódicos, naquele tempo, bem inocente, em que um dos esportes das pessoas era pegar fio elétrico, ficar todo mundo de mãos dadas, ligar as pontas na tomada e levar choque [risos]. Aquilo era uma alta curtição, ouvindo Janis Joplin e Jimi Hendrix. Estava no espírito da época, também. Eu vejo isso e me divirto. Era uma coisa comunitária, mas mesmo ali você já tinha classes. Tinha o Rio Apa, os filhos do Rio Apa, eu, que era um puxa-saco do Rio Apa... Eu mesmo me gozava, na Sopa de legumes, uma novelinha em capítulos que eu escrevia para nós mesmos, sobre isso [risos]. Daí tinha a turma da Dolores, que era um pessoal mais radical, e tinha os mais profissionais, o Ariel, um pessoal de teatro, de Curitiba. Era um bando bem curioso. É engraçado...

Benito - Eu queria voltar a Uma noite em Curitiba. Na altura em que você estava trabalhando na adaptação teatral do Trapo, ocorreu-lhe a idéia de trabalhar certos aspectos que não tinham a ver necessariamente com o enredo do romance, mas com procedimentos, explorar certos aspectos que vieram a desembocar no Uma noite em Curitiba. Esse romance você escreveu na América do Norte?

Cristovão - Certo, certo. 
Benito - À medida que a narrativa vai avançando, vê-se o quanto a existência do filho é essencialmente uma experiência de segunda ordem em relação àquela do pai, de tal forma que o próprio gesto de suicídio, no final, aponta para uma, digamos assim, dimensão de radicalidade absolutamente fora da perspectiva do que o filho pudesse pretender, querer ou desejar. Então, eu fico pensando: a narrativa, o ato de escrever, na origem, era visto como afirmação da possibilidade de transformar o mundo, escavar o seu lugar no mundo, e também escavar um lugar na linguagem. Se não há remissão possível, se a única remissão é você pular do alto do edifício em São Paulo, depois de vinte e cinco anos, e, no mais, negociar pelo melhor preço com o primeiro editor essa experiência toda, do ponto de vista da construção de um mundo, de um lugar possível, onde isso nos deixa? Se não há remissão possível, então o gesto de escrever nos coloca onde?

Cristovão - Eu acho que talvez a gente vá voltar ao Aristóteles e à velha noção de catarse [risos]. E algo que é herança dos anos 60 e do Rio Apa, também. Um teatro sem palavras. Pela purgação das misérias, você se torna uma pessoa melhor. A literatura não é apenas a hora da chegada. $\mathrm{O}$ processo de escrever, para mim, é um reconhecimento do mundo, é um recorte, é uma reorganização. Isso é até um chavão, dizer isso é um lugar-comum, mas eu acho que é isso mesmo: o romance é um mundo reorganizado segundo certos prismas. Eu tenho uma relação muito próxima com o que eu escrevo, então também tem o lance da intuição. Acho importante descobrir coisas que vão surgindo, aceitar essas coisas, não me submeter completamente a um esquema prévio. Não vou totalmente sem esquema, isso eu nunca fiz. É visível que os meus romances têm algum esquema... E repartir experiências, a comunhão. De repente as pessoas estão lendo, eu estou falando uma linguagem que é comum a essas pessoas, é um processo... [pausa] Mas eu acho que a literatura não serve para nada, mesmo [risos].

Marcelo - Aproveitando um pouco essa última declaração: o que nós estamos fazendo aqui, afinal de contas, a essa hora da noite, numa sexta-feira? Talvez haja um lado masoquista, aí, da parte do escritor...

Raquel - E sádico, nosso. 
Marcelo - Eu fico pensando com relação a certa ética do escritor diante da publicidade. Se a gente pensar em certas figuras locais emblemáticas, Dalton Trevisan e Leminski, que são sempre lembrados, que são importantes localmente e conseguem uma projeção para fora: são autores que, nessa relação com a publicidade, estão nos antípodas. O Dalton nesse recolhimento, nesse enclausuramento maluco, não é? E o Leminski nesse desvario de tentar roubar a cena o tempo inteiro, de querer se colocar no centro dos acontecimentos e de ter construído sua carreira muito em função desse modo agressivo e arrojado mesmo...

Cristovão - É verdade...

Marcelo - ...ter saído daqui, ter conseguido uma interlocução com gente de fora. Além das suas qualidades como escritor, a manutenção do nome dele para um certo público se dá em função disso. Ele continua sendo alguém comentado por gente que tem voz na imprensa cultural. Não no meio, mas talvez cm uma terceira ponta do triângulo, você tem uma outra relação com isso, não é? Você está aqui, estả ocupando o espaço da Universidade. Tanto o Leminski quanto o Dalton fogem desse universo. Você é um professor na Universidade e se dispõe a conversar com um público de alunos. Faz parte da tua trajetória como escritor tentar construir - você quis negar a palavra "carreira" literária, mas... - faz parte das estratégias de construção de uma carreira literária, Cristovão?

Cristovão - Eu acho que é boa essa pergunta, porque eu pensei muito sobre isso em vários momentos da minha vida. Primeiro, eu fui muito massacrado. Curitiba massacra. É o que eu disse: você faz uma produção, não acontece nada, ninguém toma conhecimento, não existe. Eu fui meio vacinado com isso, e aprendi a não dar muita bola. O Leminski fez o quê? Saiu dando porrada em tudo, foi para São Paulo, etc. O Dalton, talvez sabiamente, se refugiou, porque ele é o retrato da cidade, de certa forma, de uma timidez curitibana. É uma coisa muito autêntica, e o pessoal às vezes não sabe lidar com isso.

Eu comecei a aparecer depois do Trapo. Antes eu podia sair correndo, dizer "Olhe pra mim aqui, pronto para dar uma palestra!" [risos] e ninguém me chamava para nada. Então, discretamente, eu me recolhia à minha insignificância, e deixei que as coisas acontecessem naturalmente. 
Depois, não. Com o Trapo, eu entrei, digamos, no grand monde, nesse pequeno mundo literário [risos] meio traumaticamente, porque o Trapo foi uma página da Veja. Isso significou muita coisa para alguém que não tinha saído em lugar nenhum. Um ilustre desconhecido, leva uma porrada do Leminski já dentro do próprio livro. Era uma situação esquisita... O Nicolau, em oito anos, acho que citou o meu nome duas vezes. Sempre vivi uma relação extremamente distante da cidade comigo. Aí eu disse assim: eu tenho que obedecer a minha maneira de ser. Primeiro, não me envenenar. Isso ocupa muito espaço, eu sou uma pessoa muito sensível. Então você tem que se proteger, não se expor muito. Tomei alguns cuidados em relação, por exemplo, à imprensa - depois que comecei a trabalhar com editora grande - de mandar livros pra jornais, pra quem deve ser, para divulgação, é claro. Mas jamais pedi a nenhum jornalista para escrever sobre mim, não correr atrás, não me desgastar com esse processo, o que eu acho uma atitude interessante. $\mathbf{E}$ claro que muitos artistas fazem isso naturalmente - em algumas áreas essa luta é realmente obrigatória, como teatro e música, é verdade -, com a justificativa correta de que você está fazendo bem para a humanidade. "Não, isso é uma coisa legal, pô! As pessoas têm que dar bola para a literatura, a arte e tal..." Eu, por timidez, não faço. Acho que é medo de ser recusado, o cara dizer "Eu não vou comentar essa bosta!" [risos] Por um lado, isso cria um certo problema, porque parte do jornalismo trabalha em cima desse incensamento. As pessoas gostam que você telefone, ligue. Mas, por outro, você passa a ser mais respeitado. Você acaba ocupando um espaço talvez quantitativamente menor, mas qualitativamente melhor. Enfim: acho que o principal é simplesmente obedecer ao temperamento. Às vezes você pensa, porque dá vontade mesmo: vou ser igual ao Dalton, não vou falar com mais ninguém. Eu vou me sentir ridículo [risos]! Eu não sou assim! Eu sou um cara que adora conversar, bater papo com as pessoas, quer dizer, eu não vou me esconder agora só por um projeto público.

Procuro ser o que eu sou, com alguns cuidados. Profissionalizar, manter uma certa distância curitibana, isso é sempre saudável. E às vezes as pessoas até me entendem mal. Isso para uma certa faixa é uma coisa normal: é legítimo você batalhar pelo teu livro, sair correndo, levar lá. Isso eu não faço mais de jeito nenhum. Acabei institucionalizando essa tarefa via editora. Eu acho que está dando certo, eu estou me sentindo bem, tenho tido uma relação boa com a divulgação do meu trabalho. Agora, é claro... É uma coisa que faz bem, essa vaidade. O cara tem, 
mesmo. Você escreve um livro, você gosta que as pessoas falem, escrevam. Mas meio à la Curitiba, também [risos]. Uma coisa eu procuro manter viva: o meu projeto de escritor foi, desde o início, um projeto existencial, meu, pessoal, intransferível, que não pode depender de nenhum tipo de resposta.

Luís - Você reclama um pouco que Curitiba te tratou mal. Você não acha que tem um lado bom nisso? Eu estou há pouco tempo aqui, mas cu sinto o seguinte: se o cara faz sucesso em Curitiba, ele não vai fazer sucesso em lugar nenhum do mundo porque Curitiba valoriza demais esses pequenos valores locais, os incensa e essa vaidade de que você está falando já fica satisfeita e o cara nem sequer vai pensar em ir mais longe. Então aqui tem esse espaço cativo, guardado, para quem cai nas graças disso - e que acaba caindo inclusive nas graças do financiamento oficial para sua obra. Em vez de ser um trampolim acaba virando um poço. Isso é verdade?

Cristovão - Eu acho que sim. E tem um aspecto de Curitiba que é extremamente perigoso para quem lida com arte: é o oficialismo. Isso é um reflexo também do tipo de imprensa que nós temos aqui. Ela é absolutamente servil, é um braço estendido do governo - qualquer governo, historicamente. Até não é caso de meter pau nem brigar, é só constatar: todo mundo sabe disso, quem trabalha em jornal sabe. Aí você começa a entrar no tipo do poeta oficial, do artista oficial. O Poty entrou numa dessas. $O$ Poty era o artista plástico do Lerner nos últimos vinte anos - o traço dele, as coisas que ele fez. Um grande artista, um gênio, fez coisas magníficas, mas ele foi devorado pela cidade, foi oficializado. Então, nesse sentido, manter essa solidão é muito bom.

Raquel - Já que a literatura não serve para nada, você tem um próximo projeto em vista?

Cristovão - Não, eu dei uma parada na cabeça. Eu tinha um projeto, comecei a esboçar, comecei até a fazer leitura sobre fotografia. Eu estava começando só o tema, depois ia entrar o fotógrafo [risos]. Agora eu suspendi. Agora eu vou fazer esse doutorado, estou começando a ler. Estou lendo A cidade e o campo [Raymond Williams], estou lendo Joseph 
Brodski, leituras de ensaio, mesmo. Quero dar uma suspirada e ler bastante teoria, ler ensaio, principalmente.

Raquel - Não tem nenhuma obsessão que você esteja precisando polir?

Cristovão - Não, não amadureceu. A obsessão agora é fazer um trabalho de leitura. Queria ter mais tempo de ler mais caoticamente, ler de tudo, me aprofundar. A fotografia é uma outra coisa que eu sempre gostei - é a questão das artes visuais e tal. E os fotógrafos são figuras muito interessantes, não é? [risos]

Patrícia - O personagem do próximo livro vai ser um doutorando [risos].

Cristovão - É, um doutorando da USP, ainda.

Benito - E pode ressuscitar o professor Rennon assombrando a USP...

Cristovão - Vai fazer uma tese sobre a obra do professor Rennon, $A$ Escravatura no Brasil Colonial [risos].

Benito - Aí você divide o copyright com a gente [risos]. Obrigado, Cristovão. 